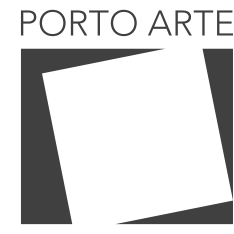

Revista de Artes Visuais

, 25 n. 44 $\mathrm{Jul} / \mathrm{dez} 2020$ e-ISSN: 2179-8001

\title{
Línguas sem posse - em direção a um inconsciente menor institucional
}

\author{
Language without ownership - towards an institutional \\ minor unconscious
}

\section{Cristina Thorstenberg Ribas}

Orcid 0000-0001-6856-1937

Universidade Federal do Rio Grande do Sul

\section{Paula Cobo-Guevara}

Orcid 0000-0002-7056-0412

Pontifícia Universidade Católica de São Paulo

\section{Resumo}

Como podemos pensar um insconsciente institucional, hoje?; e o que ele nos diz das práticas menores que uma instituição pode abarcar? Pensamos, com esse artigo, que o movimento de instituição e destituição a partir de um inconsciente menor institucional tem mais a ver com um procedimento de passagens, que modifica e arrasta a instituição em direção a um fora. A subjetividade é matéria, é agenciada nesse arrasto, e com os pés no chão, é possível produzir singularidades por contágio e vizinhança. Apontamos como uma saúde menor pode dar passagem a movimentos instituintes, como ela também elabora uma processualidade estética (reconceitualizando afetos na e da arte), e como se pode cartografar seus circuitos, que sempre escapam a intentos de representação.

Palavras-chave

Análise institucional. Inconsciente. Instituições. Estética. Clínica

\begin{abstract}
How can we think about an institutional unconscious today? And what does it tell us about the minor practices that an institution can embrace? The movement of institution and destitution from a institutional minor unconscious has more to do with a procedure of making-passage, which in itself modifies and drags the institution towards an outside. Subjectivity is matter, it is rearranged in this dragging out, and with your feet on the ground, it is possible to produce singularities through contagion and neighbouring. We point out how a minor health can give way to instituting movements, how it also elaborates a processual aesthetics (reconceptualizing affections in and of art), and how one can map out its circuits, which always escape the intent of representation.
\end{abstract}

Key words

Institutional analysis. Unconscious.Institutions. Aesthetics. Clinics 


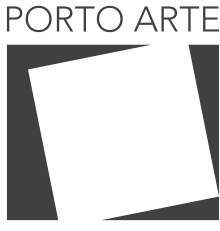

Revista de Artes Visuais

$\vee 25 n .44$

$\mathrm{Jul} / \mathrm{dez} 2020$ e-ISSN: 2179-8001

Que imagem absurda, pensar um inconsciente institucional ${ }^{1}$. De repente, dar-se conta dessa imagem. É preciso mergulhar numa trama radicular e deixar aparecer o terreno de onde emerge. Como emerge tal personagem conceitual. E o que ele desmonta, recalca, fala, pulsa, faz. Não estamos seguras sobre o que isso institui e destitui ao mesmo tempo, num mesmo movimento. Porque o problema não é o que se institui ou se destitui, mas quais são os afetos-movimentos que pedem passagem e como nos deixamos afetar por eles. 0 que se destitui e institui não é um par opositivo, binário. Como inconsciente, como topologia, não é antagônico, é dizer que seus sentidos e sua falta de sentidos operam juntos. Observar esse movimento de instituição e destituição tem mais a ver com um procedimento de passagem. E com dizer como se dá passagem a esses movimentos, como se pode cartografar seus circuitos.

O inconsciente institucional não têm um nascimento, mas um expulsamento, por mais que qualquer outra coisa. Não se desenha o inconsciente institucional, mas se encontra seus traços, suas marcas, suas palavras, em definitivo podemos nos dar conta disso quando olhamos para onde estão paradas nossas pernas e nossos pés. Isso nos fala de uma posição, uma posição de movimento-movimentação. Tudo está em movimento, não é casual que François Tosquelles (1912-1994)², psiquiatra catalão, nos fala que as mães não fazem carinhos na cabeça do bebê, mas nos pés do bebê, já que o importante é manter o tônus. Algo desta imagem nos faz ressonância com o mundo dos cachorros, planteado em $O$ que nos ensinam os animais sobre política - Brian Massumi atualizando a um Gregory Bateson - propõe que a briga e o jogo, para alguns animais, é uma forma de duplo agenciamento, ou seja, brigam para jogar e brincam para lutar. Disse: "No mesmo gesto, a luta e o jogo entram numa zona de indiscernibilidade, sem que suas diferenças sejam apagadas. A zona de indiscernibilidade é onde a diferença se ativa (Massumi, 2014, p. 23). Enquanto nos posicionamos nos movemos como animais. Isso é dizer que não sabemos se estamos nos afastando de uma posição, entrando em outra, ou movendo-nos de uma a outra, tanto faz. 0 seminário de Sainte Anne, por Jean Oury (1924-2014) ${ }^{3}$, nos transmite que, como os animais, o que importa é o movimento e a circulação. A circulação pelo espaço, e a consciência ou a implicação com esse espaço é o que permite os encontros.

A posição como passagem, ou "teletransporte amoroso"4 não se refere à viagem de um ponto a outro, é antes sua circulação, sua experiência, seu circuito de fuga, sua deriva, sua errância. Sua encarnação viajante, estrangeira. Tanto na passagem como

\footnotetext{
1-Este texto acompanha e dialoga com o dossiê que elaboramos para a Revista Porto Arte $\left(n^{\circ} 44\right)$ intitulado "Instinto e Instituição: desbordes institucionais entre a estética e a clínica", para o qual convidamos um grupo de autores a publicar

2-François Tosquelles foi um psiquiatra catalão que tornou-se referência na psiquiatria institucional no contexto do entre-guerras e pós guerra europeu.

3- Jean Oury foi um psiquiatra e psicanalista francês, fundou a clínica La Borde, onde trabalhou toda sua vida, também ao lado de Félix Guattari. Ao longo de muitos anos Oury realizava seminários na clínica, que foram reunidas no livro "O Coletivo: o seminário de Sainte-Anne" (Le collectif : le séminaire de Sainte-Anne) (1999).

4- Guattari em "Psicanálise e Transversalidade", define a transferência, no sentido de um meio de trans porte, um tipo de transporte amoroso. Pelo que entendemos, Guattari utiliza esse conceito para definir as condições do sujeito inconsciente em relação ao "doente" e ao "normal", ambos alojados no princípio da cidadania. Em outras palavras, as noções de normalidade seriam definidas a partir da noção de cidadania. A transferência entendida como teletransporte amoroso seria, então, uma espécie de passagem, que desloca as noções de normalidade, patologia, saúde. (Guattari, 1976, p. 63)
} 


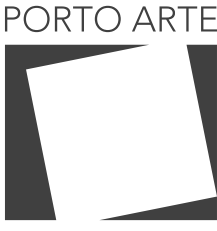

Revista de Artes Visuais

$\vee 25 n .44$

$\mathrm{Jul} / \mathrm{dez} 2020$ e-ISSN: 2179-8001

na viagem há algo do estrangeiro, algo daquele corpo não muito bem definido, ou este que se perde, que se transforma, enquanto há movimento, mudança de geografia, de contornos. A posição como passagem tem alguma coisa dos limites, das fronteiras, uma certa transgressão, um cruzamento, um salto. Um salto através das paredes dos controles de imigração, da distinção opositiva entre viajantes e migrantes.

Jean Oury nos conta em O Colectivo (2009), que o que importa não é a posição ou o discurso - referindo-se aos 4 discursos de Jacques Lacan - mas a passagem entre os discursos. A potência de passagem, para que estes não fiquem estáticos. Movimentos do desejo? Bom, segundo a orientação Lacaniana, o discurso analítico e o discurso do desejo, do inconsciente, da ética analítica é a ética do inconsciente. Desde esta perspectiva, o objeto a opera na posição do analista. Não é casual que Lacan tomasse várias entrevistas preliminares para escutar entre outras coisas as demandas, segundo esta lógica uma das formas de entrada no campo da transferência em seu leitmotiv mais clássico do desejo como falta. Mas, além desta discussão sob o desejo -a produção deste-, e seguindo os cheiros e huellas do Oury, em relação aos movimentos, se poderia pensar o "objeto a" ou a posição do analista e sua ética do inconsciente como um objeto transicional (Winnicott, 2019, p. 18). Esta imagem do objeto transicional como o discurso analítico nos sugere, nos fala de um avatar analítico mais conectado com o jogo, a viagem e o movimento. Segundo Winnicott, o objeto transicional tem características similares com a viagem do bebê a zonas estrangeiras, além do campo de órgãos afetivos (Elisabeth von Samsonow, 2019, p. 5) do papel materno. Portanto, quais são esses componentes de passagem para aceder ao desejo, ao inconsciente, à sua decifração, suas topologias estrangeiras? Seu além de si mesmo, seu além do sujeito, inclusive sua além da subjetividade. Sua pulsão anti-electra, anti-narcísica, ex-niilista?

Por que a soberania do inconsciente, em seu registro de decifração ética (Schiavon, 2019) tem a ver com o lapso, o sonho, são esses os componentes de passagem. Mas nossa branquitude, nossa classe, nossa concepção da neurose como garantia de saúde, nossa cultura da dominação nos inibe, proíbe, castiga e cinde (rompe) de entrar em um outro plano da experiência como seres vivos. Um acesso que as cosmologias dos povos indígenas cuidam e conservam, elxs sabem que a saída a um impasse, está no sonho, "a porta de entrada e a porta de saída está no sonho" (Rolnik, 20185). Por exemplo, Barbara Glowczewski em Devires Totêmicos, Cosmopolítica do Sonho (2015) nos conta como os aborígenes Walrapi co-produzem cartografias dos territórios pelos quais a suas "grupalidades" vão circulando e movem- se, enquanto anti-estatais (o estado em nós), traçam seus circuitos e linhas de viagem (ou fuga) junto com o sonhar coletivo, um saber menor 6 .

\footnotetext{
5 - Notas seminário de pós-graduação, no Núcleo de estudos da subjetividade, PUC-SP junto com João Perc Schiavon, na disciplina de Pragmatismo Pulsional, Clínica Psicanalítica.

6- Ailton Krenak é um dos pensadores dos sonhares contemporâneos, a partir de sua etnia Krenak. Ele nos conta como o sonho é "a casa do conhecimento" (Krenak, 1992, p. 202), mais do que experiência onírica buscam-se nos sonhos "as orientações para as escolhas do dia a dia" para conversar com os "fundadores do mundo" (idem p.52). “Antes, o mundo não existia”. Em: Novaes, Adauto (org.). Tempo e história. São Paulo: Companhia das Letras, 1992. p. 201-204
} 


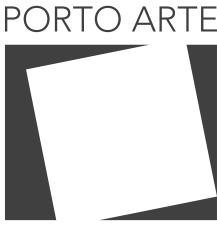

Revista de Artes Visuais

v $25 n \cdot 44$

$\mathrm{Jul} / \mathrm{dez} 2020$ e-ISSN: 2179-8001

\section{A saúde menor da instituição}

0 inconsciente institucional, enquanto personagem conceitual, poderia ser pensado como um campo topológico, onde a pulsão (no que existe, diz, reage) caminha, recorre, atravessa zonas, realiza deslocamentos, errâncias. Fala desde a mesma posição de passagem; suas zonas de borda, de fronteira: seu pragmatismo de errância menor. É dizer, uma micropolítica das forças que atravessam esse campo instituído (e destituído). Procura, cria e antecipa, seu movimento. Uma sorte de destino pulsional da instituição, onde o que se afirma (produz) e uma saúde menor de aquilo instituído. Pode-se dizer que é uma minoração de aquela língua maior (Deleuze) - aquele comando que fala e age através de nós - da instituição. 0 destino menor da instituição seria aquele movimento que escapa, foge, destitui, e "arranca da existência a vida onde ela está aprisionada, equilibrada, estabelecida, submetida a uma forma majoritária" (Pál Pelbart, 2018, p. 68). Poderíamos dizer que a saúde menor da instituição é justamente a capacidade de destruir, traspasar fronteiras, desbordar-se, revelar-se: instaurar uma passagem. "A neurose é onde o movimento está em interrupto, fechado, estancado, sem movimento" (Deleuze, 1993, p. 8). De certa forma a docência seria um marcador de saúde da instituição, no sentido que para restabelecer uma saúde menor da instituição, só falta ficar doente para aceder às passagens de cria-acção: parto, aborto, sofrimento, e destruição da instituição. Por tanto, um inconsciente institucional que fala desde sua consistência ética-vital é aquele que se revolta, se move e dá duração àquele movimento entre o que destitui e institui, no meio dessa vibração. Definitivamente, é a autorização da tensão dessa duração. Foge de qualquer forma policial, qualquer comando de palavras e funcionamentos fora de nossa potência vital, da pragmática do inconsciente molecular.

Toda instituição se impõe a nosso corpo, inclusive nas estruturas involuntárias, uma série de modelos, e otorga nossa inteligência a um saber, uma possibilidade de previsão como de projeto (Deleuze, 2004, p 21). Traduzindo em outras palavras ou pluralizando o sentido dessas palavras emprestadas em Instinto e instituição, a instituição ou esse inconsciente institucional, pode ser pensado como a possibilidade de produzir projéteis de pensamento, armas para defender-se (Elsa Dorlin, 20187) da instituição em seu sentido policial ou estatal: fazer a resistência, fugir, clandestinar. Agora bem sabemos que o que produz o pensamento não são as ideias, os modelos, as imagens, mas é a violência (Deleuze + Guattari), e não é qualquer violência, mas é o encontro com o Fora (Foucault), são as experiências limites do corpo, da subjetividade, da linguagem. São os devires que nada tem a ver com o dado, o contornado, o idealizado, o planejado, inclusive o humano. Porque mais bem tem a ver com o selvagem, o animal. Com os devires selvagens da instituição. São as torções Nietzschianas, da transmutação de todos os valores, daquilo humano, demasiado humano. Não é casual que os humanos não tenham instintos, como aponta Deleuze, eles só têm instituições (2004, p. 21).

Tem mais haver com os devires mulher, que não tem nada a ver com ser mulher ou parecer-se a uma mulher, tão pouco liberar-se de ser mulher (Deleuze, 1996, p. 168), 


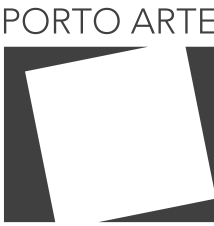

Revista de Artes Visuais

V. $25 \mathrm{n} .44$ Jul/dez 2020 e-ISSN: 2179-8001

Figura 1: (Foto) Still de video da greve feminista $8 \mathrm{M}$ (Uruguai), 2020. Antifascista antiextractivista; contra la justicia patriarcal; contra la cultura transodiante y lesbodiante; será migrante. anticapitalista; antipunitivista contra la violencia sexual, la trata y el acoso; antimanicomial y contra el encierro; será por

una educación antipatriarcal por maternidades y crianzas

libres; por vidas dignas,

libres y gozosas; será por un feminismo antirracista o no será! Video completo no link https: //ar-ar.facebook com/152357398168947/ videos/534695127252618/ mas os devires mulher como chave de passagem a todos os outros devires (Deleuze e Guattari, p. 239). Arrastar-se em si mesma, como se fosse um rastejo nas imagens que nos regalaron quando niñes: na infância do mundo em forma de uma bailarina pós nuclear doente (Kuniichi Uno, 2018, p. 58). Um rastejo de dúvida, corpo ao rés do chão, arrancando solo por baixo ao fazer-se mover. Com as coxas roçando o solo. Um devir situado no território, nos cheiros ainda que cheiros que nos causem repulsa. Instinto da matéria circundante. Mas, além dos sensos comuns em torno aos devires, poderíamos falar em um devir mulher nos processos de feminização da instituição e destituição, é dizer, colocar a vida no centro da instituição, apequenar os valores e as performances da masculinidade; é dizer ultrapassar os modos e modelos de dominação e submissão do corpo, do pensamento, os modos de validação, penetração e percepção. E mais um pensar-fazer desde um terceiro corpo, um corpo lésbico, que não é nem homem nem mulher (Monique Witting, 1975, p. 15). É um devir niña, menina-anti-electra (Elisabeth von Samsonow; 2019) além do homem como diz Nietzsche. Pensar como um bebê, com o estômago, com o peito, com esse saber que não sabe que sabe, com esse saber do corpo, esse que nos foi expropriado.

Von Samsonow propõe a figura da menina como um "perfume latente" das novas formas de produção de subjetividades transgressivas e infraestruturas do planeta, fora do regime patriarcal. Escreve: "La estructura subjetiva es para el psicoanálisis un resultado producido en los atolladeros de la metáfora paterna" (2019, p.2). Neste sentido, a menina, como uma figura clínica, e contemporânea às formas de culturas feminizadas instituintes e destituintes : "tipos de estructuras sociales que se organizan alrededor de networks, nubes electrónicas, intra(nets), satélites, conexiones wireless", mas também os movimientos ecológicos actuales, tecnopolíticos, o movimientos por la "feminización de la existencia" (Coordinadora Feminista 8M, Chile) ${ }^{8}$.

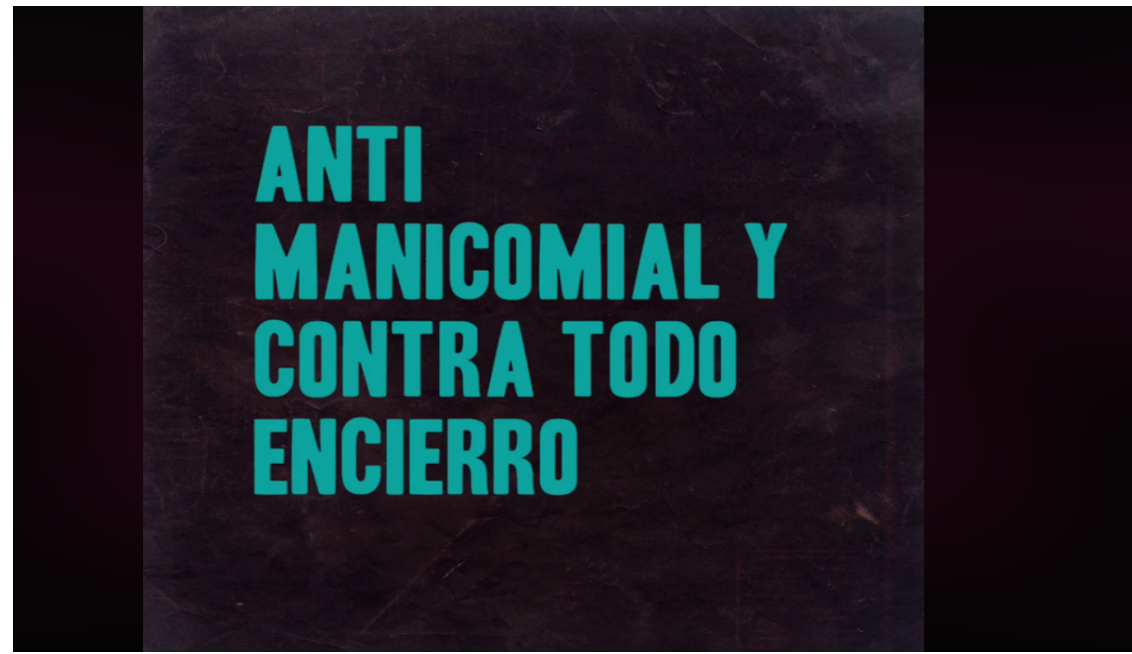

8- A Coordinadora Feminista $8 \mathrm{M}$ é uma campanha feminista Chilena que organiza entre outras lutas a Greve Internacional Feminista no Chile, a luta pela legalização do aborto e a aprovação de uma nova constituinte no Chile, ocorrida em 2020. <https://twitter.com/coordinadora8m> 


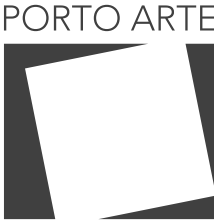

Revista de Artes Visuais

V. $25 \mathrm{n} .44$ Jul/dez 2020 e-ISSN: 2179-8001
Figura 2: François Tosquelles, em still de filme da entrevista realizada em 1989 por François Pain, "Une politique de la folie". Entrevista completa disponíve no link < https://vimeo com/167991974>

\section{Re-traçar, histórias}

Uma conversa acontece entre muita gente com François Tosquelles em 1987. Encontramos essa conversa num livro editado em 1994. O livro foi comprado em 2020. A conversa com Tosquelles desejava recuperar mais detalhes da história da psiquiatria institucional nos anos 40 e 50 na França, especialmente na relação entre a psiquiatria italiana e francesa (Gallio e Constantino, 2009, p. 86-87). Que este grupo de pessoas, psiquiatras, psicólogos, pesquisadores, e profissionais da psiquiatria francesa tenham se dirigido à casa de Tosquelles no vilarejo de Grange sur Lot, e ali ficaram por três dias, nos faz pensar sobre a importância de escutar-nos e de contarmos histórias que sejam as narrativas das experiências coletivas e institucionais. Mais do que as individualidades que se endereçam à casa deste homem, vemos um corpo institucional ou uma instituição sem corpo, vemos juntas esse corpo-mais-que-humano. Um corpo institucional menor, aberto, móvel, é também algo de uma sabedoria espacial. Experiência da ordem de uma reconfiguração do espaço, do espaço da clínica psiquiátrica hospitalar, que se move como se tivesse muitos braços, e por isso mesmo devém tentacular. Escutar Tosquelles e conversar por três dias resultou num texto de 120 páginas. No livro (de 1994) encontramos uma versão curta da transcrição da conversa. E é na forma da conversa, pergunta após resposta, que vamos entendendo as "posições circulares" que organizam esse encontro (p. 85).

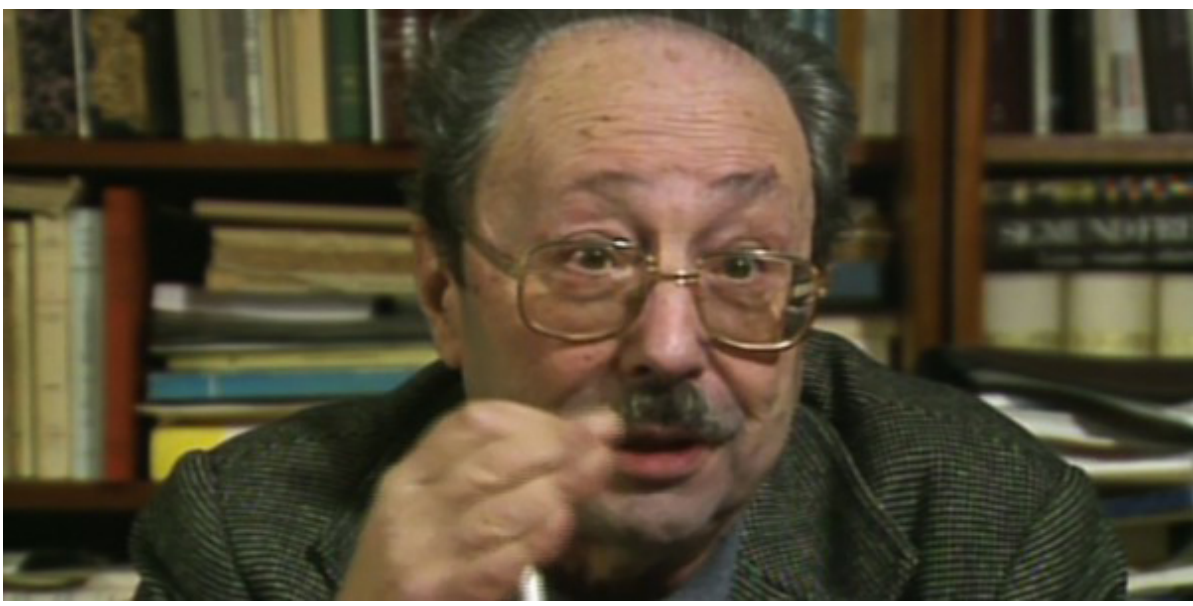

A história de Tosquelles é repleta de deslocamentos, e da produção de desvios. A profissão da psiquiatria, para ele, mais deformava que formava, podendo mesmo gerar uma espécie de fobia da loucura. Por isso Tosquelles optava por criar equipes mistas, evitando muitas vezes contratar psiquiatras, como quando foi encarregado médico-chefe dos serviços psiquiátricos do Exército, quando criou a Comunidade Terapêutica em Almodóvar del Campo (no contexto do Franquismo). Foi ali que recrutou pessoas sem formação específica para atuar como agentes de saúde (Ruiz et al, 2013, p. 857), prática que levaria adiante em suas ações e intervenções institucionais. Neste momen- 


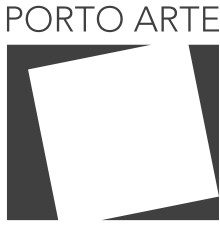

Revista de Artes Visuais

v. 25 n. 44

$\mathrm{Jul} / \mathrm{dez} 2020$ e-ISSN: 2179-8001

to, Tosquelles criou um serviço que pudesse atender aos médicos eles mesmos, visto que segundo ele os médicos tinham uma formação burguesa e a guerra lhes causava extremo distúrbio. Era preciso cuidar, portanto, também da saúde mental dos próprios médicos. Em 1939, para manter-se vivo, Tosquelles foge para a França e leva consigo essa experiência institucional - o risco da aposta na relação estabelecida entre os cuidadores e os pacientes, apostando na ausência de preconceito em relação ao sofrimento psíquico. Na França, Tosquelles se depara com a falta de recursos que dessem conta da gravidade dos transtornos mentais então emergentes (idem), também devido ao contexto violento da guerra. Depois de grande precariedade de vida e trabalho, ele se estabelece, a partir de uma rede de amigos psiquiatras, no Hospital de Saint Alban, onde dá continuidade a seu trabalho (e onde Frantz Fanon também trabalha anos depois). Tosquelles era atento às fronteiras, e portanto às passagens. "Neste contexto de guerra e precariedade, eram atraídos voluntários e uma característica valorizada era a competência de estar e saber viver com os outros." (Ruiz et al, 2013, 862-863). Tosquelles não queria a instituição fechada aos especialistas, queria fazer da clínica mais um asilo que um hospital, um asilo que pudesse acolher a qualquer um.

No período de ocupação e guerra nazi-fascista, Saint-Alban se afirmou como um local de passagem e de acolhida, tendo recebido refugiados oriundos de diferentes campos, seja de intelectuais a artistas, judeus, militantes da Resistência. É neste sentido que Tosquelles diz preferir a denominação Asilo. (Ruiz et al, 2013, p. 860)

Tosquelles estava atento à necessidade de atravessar fronteiras, em como se precisava atravessar os estados nacionais (em vários sentidos), pelas bordas não mapeadas, não policiadas, daqueles que precisavam escapar de regimes de controle (quem não precisa?). Nos interessa atentar aqui para a importância da passagem, assim como para o "estrangeiro" em toda parte. ${ }^{9}$ Efeitos, efeitos...

No Brasil, as histórias da análise institucional se cruzam com a decolonialidade na educação popular (com Anísio Teixeira e Paulo Freire) e na universidade pública, e vem sendo escritas pelos próprios atores desta história (Osvaldo Saidón, Vera Kamkhagi, Cecília Coimbra, Heliana Conde Rodrigues, Gregório Baremblitt, Regina 


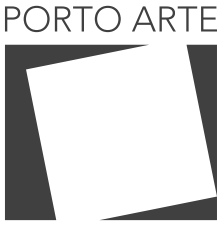

Revista de Artes Visuais

v. 25 ก. 44

$\mathrm{Jul} / \mathrm{dez} 2020$

Benevides de Barros, Virgínia Kastrup $)^{10}$, assim como por gente mais nova que vem retraçando essas contaminações (Domenico Uhng Hur, Francine Guizardi, Renato Sampaio Lima, Alice de Marchi, entre muitos outros). Ao olhar para essa história nos deparamos com muitos encontros, infindáveis encontros, assembleias, reuniões, debates, ora denúncias, ora protestos, inventando modos de estar juntos. As articulações que se inventam aí entre espaços institucionais dilacera o encerramento de uma única instituição, desafia as suas formas de conservação. Seus efeitos chegam até hoje: intervenção molar, política de cotas, ações afirmativas, crítica à militarização da vida e à violência da polícia. A frase completa fica: Seus efeitos chegam até hoje: intervenção molar, política de cotas e ações afirmativas nas universidades, crítica à militarização da vida e à violência da polícia.

Na recuperação de fragmentos, sempre fragmentos dessa história, pensamos em como esses processos são residuais porque deixam ver pedaços de identidade, pedaços de vida nos seus percalços, porque aquelas identidades que foram desinventando os modos duros inventaram espaços para si, aparecendo, na remontagem desses fragmentos, a composição entre classes sociais, raça, urgências, ..., são políticas, afinal, de invenção, e de subjetivação. Por isso, a história da análise institucional é também a da recuperação ou recomposição das identidades fraturadas, partidas, machucadas, feridas pelo estado. ${ }^{11}$ Tratam-se de fugas internas, e externas, produzindo foras e exterioridades, modos de subjetivar, e existir.

\section{Fumaça, humo, pista, perder-se (na fumaça...) contagiar-se}

Um espaço no qual não se vê, mas se tateia, pelo faro, pero cheiro das coisas, se é que há coisas. Ao passo que as artes podem ser o lugar do problema da representação, é no registro dominante da dominância da representação que temos visto que ela perde muito da sua capacidade de afeto. Escolhemos essa fumaça, escolhemos perder o registro da representação, como forma de encontrar os afetos os modos de afetação por fora da representação - e porque não, um caminho de escuta das intuições. Inclusive do criar. Para criar, às vezes é preciso abandonar algumas coisas e estabelecer ou-

\footnotetext{
10- A análise institucional tem muitos atores na América Latina, no Brasil, e nas conexões que se estabeleceram com países Europeus e Africanos. As genealogias nos mostram a influência do trabalho de René Lourau, Georges Lapassade, Franco Basaglia, Emilio Rodrigue, Félix Guattari, Frantz Fanon, entre muitos outros e outras, e claro-escuro, as viagens de Michel Foucault, antes ainda, nos anos 60 (organizadas por Heliana Conde). A análise institucional, rizomática que é em sua pragmática e desenvolvimento conceitual e teórico, se desenvolveu em muitas vizinhanças com a teorias decoloniais, a socioanálise, a esquizoanálise, o esquizodrama e mais. No Brasil foi também mobilizada pelo que se auto-denominava "movimento institucionalista". Foi e é aplicada e desenvolvida desde as instituições psiquiátricas, clínicas psiquiátricas grupos auto-organizados, universidades, instituições comunitárias, escolas, centros de atenção psicossocial (CAPs) e mais. Para a história da análise institucional são referenciais os seminários internacionais organizados pelo Instituto Brasileiro de Psicanálise, Grupos e Organizações (IBRAPSI), ainda no final dos anos 70. O registro do segundo encontro foi publicado no livro "O Inconsciente Institucional", editado por Gregório Baremblitt (Rio de Janeiro: Vozes, 1984).

11- Um dos grupos ainda ativos de nosso conhecimento é o grupo Tortura Nunca Mais, do Rio de Janeiro cuja militância começa ainda nos anos de abertura política do Brasil no começo dos anos 80 . Sua luta é pela memória do período da ditadura civil-militar, contra a tortura e em defesa dos direitos humanos. Anualmente o grupo organiza a Medalha Chico Mendes, memorando e homenageando pessoas e organizações que atuam na defesa dos direitos à vida e à liberdade. Site de referência <http://www.torturanuncamais-rj. org.br/> Acesso em 15/12/2020.
} 


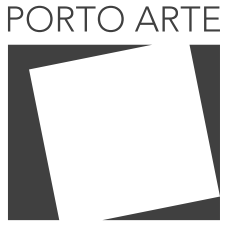

Revista de Artes Visuais

v. 25 n. 44

$\mathrm{Jul} / \mathrm{dez} 2020$ e-ISSN: 2179-8001

tras pragmáticas para a visão. Visão das forças além das formas. E a visão feiticeira, de fumaça, de cegueira das senhoras fumadoras e aborteiras -como nós- dos sentidos instituídos. As Medeias, militantes da extranjería (Stengers, 2000).

Simon O'Sullivan fala dos afetos em relação à arte, que nos servem aqui como espaço de contágio. "Queiramos ou não", diz ele, "a arte continua produzindo afetos". Esses afetos, diz ele, são certamente extra-discursivos e podem muito bem ser extra-textuais. "Afetos são passagens de intensidade, uma reação dentro ou sobre o corpo no nível da matéria. Podemos até dizer que os afetos são imanentes à matéria. Eles são certamente imanentes à experiência" (2006, p. 41). Afetos-matéria-corpórea.

Atentas aos afetos-matéria, partimos ao meio de uma série de experiências, que os autorxs mesmo nos contaram de seus processos partidos. São essas vizinhanças de práticas assim destroçadas que nos ancoram. Mais do que as caixas institucionais - e é como se tivéssemos parado de vê-las - , ficamos com os miolos, os modos, os corpos inteiros (ou aos pedaços) para recolher, ouvir e plantar.

Fazer análise é, cada vez mais, o trabalho de desestabilização do que se apresenta tendo a unidade ou a forma de um campo: o instituído, o indivíduo, o social. Do uno ao coletivo, esta é a direção da análise. Direção a quê? Não ao agrupamento, ao conjunto de indivíduos nem à unidade do diverso, mas ao coletivo como dinâmica de contágio em um plano hiperconectivo ou de máxima comunicação. (Passos e de Barros, 2009, p. 26)

Jean Oury, em continuidade ao trabalho de Tosquelles, anos depois, falava que os tecnocratas entravam na Clínica La Borde e percorrendo-a, "não encontravam nada", "não encontravam nada que fosse diferente" de outros hospitais, como lhes era explicado, relatado, narrado nas derivas de suas visitas. Os procedimentos, ali, eram outros, não os da ordem da repetição de um comando, nem da expressão do controle. Que resultados procura, então, um tecnocrata em uma clínica psiquiátrica? Que efeitos ele espera que uma instituição psiquiátrica produza? Oury falava, por sua vez, da importância do fazer algo, do conversar, da relação, do que se estabelece na troca, no contágio - diferente do que a evitação provoca. Em uma entrevista feita em São Paulo, na ocasião de sua visita em 2009 por conta de uma Ocupação Ueinzzz ${ }^{12}$, ele diz:

O Clube [terapêutico] é uma ferramenta, um operador coletivo para responsabilizar as pessoas, dar-Ihes iniciativas, promover a relação com suas famílias, não é um simples teatro, é simplesmente uma vida de todo dia, do dia a dia, a vida. Um hospital no qual não exista a preocupação com essa dupla articulação não chega a ser um hospital e sim uma espécie de clausura e as consequências são visíveis. 


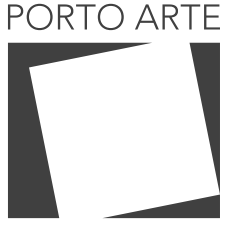

Revista de Artes Visuais

Figura 3: "Que ardan también nuestras comodidades", de Alicia Maldonado Miranda. Santiago de Chile, 27 de novembro de 2019
(...) Um verdadeiro encontro não pode ser programado. 0 caminho se faz ao caminhar, mas se o caminho já está traçado a gente sempre fica no mesmo lugar. 0 caminho se faz andando e é por acaso que pode haver um encontro, mas não é obrigatório. No fim das contas, a questão é de que não é possível organizar algo que não está previsto. Imprevisível, com a condição de que possamos ir e isso, em geral, não é compreendido. (Oury, et al. 2010)

Mas... "quando os burocratas dizem que é preciso organizar a vida coletiva do estabelecimento", ele ironiza, "nem vale a pena. Tudo estará previamente definido, não existirá acaso, não existirá surpresa, e é isso que conta na existência" (idem).

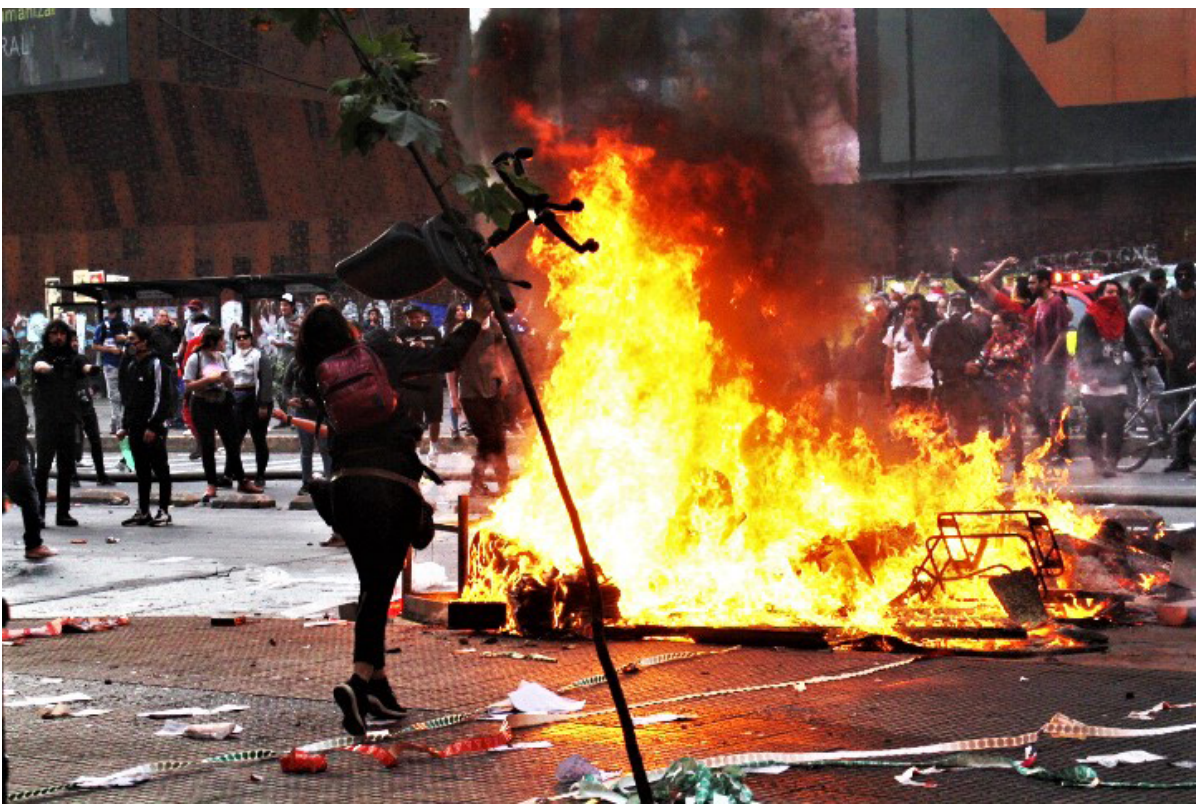

\section{Micropolíticas das palavras}

A instituição que grita, murmura, rumeia (palavra inventada). Aquela que fala em outra língua. A língua estrangeira. A instituição fala línguas em desaparecimento. Que nem se falam nesses lugares onde se falam línguas homogêneas. A língua maior instituída em sua destituição e minoração des-gramática, dyslexia. Sua coralidade mutante. A doença, de certa forma, é a voz que dá passagem, ela que pede passagem. Sabemos que todas as doenças vem da falta de palavra. Da penetração de palavras que não são nossas. As palavras de ordem (Deleuze \& Guattari, 1995, p. 19) que nos habitam, que nos invadem, que são incorporadas e que nos comandam em nossos movimentos. Onde estão seus pés parados agora? Como você chegou até aí? Que discurso tu falas? 


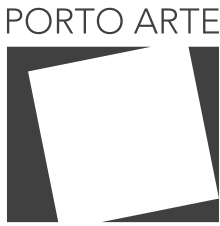

Revista de Artes Visuais

v. $25 n .44$ Jul/dez 2020 e-ISSN: 2179-8001

Figura 4: Luiz Guilherme Ribeiro Cunha e demais atores em performance da Ueinzz Companhia Teatral em Amsterdam (2016). Still de vídeo de Cristina Ribas.
Murmúrio e o grito urrante. 0 grupo se move ${ }^{13}$ e no seu interno uns elementos de desborde como se como se não fosse possível dizer qualquer coisa sem um rasgo de voz que coloca todo regime de sentidos em risco. São os gritos de intervenção estética de um homem que vem mais agachado, agarrando-se nos outros, e na modulação dos seus vários volumes (também o corpo tem volume) ele arrebenta e falamos com ele. Em um fragmento curto de tempo repetem-se aqueles sons, e a matéria mesmo do grupo se dissolveu entre meias palavras e aquela intervenção, constitutiva. Não destrutiva.

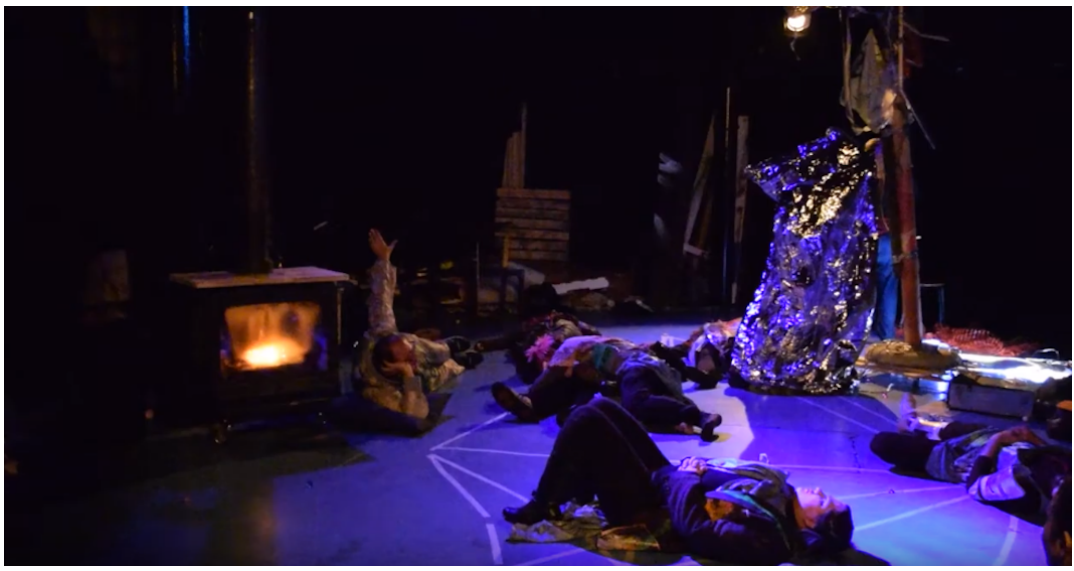

É preciso perder a própria língua (imagem de Ana Maria Maiolino). Ou falar uma língua frágil, como disse val flores em una lengua cosida de relámpagos: "una lengua de una comunidad de extraviadas que habitamos espacios intersticiales y territorios imprevistos, en la que se pulveriza toda ilusión de unidad" (flores, 2019, p. 30).

É preciso quebrar a própria língua para abandonar o ciclo dos adoecimentos psíquicos da branquitude. Para quebrar o pacto narcísico da branquitude. ${ }^{14}$ Para escapar de uma auto-análise auto-centrada, é preciso sair do lugar reincidido da verborragia auto explicativa (retórica ainda narcísica?; continuidade do lugar de privilégio discursivo?). Não basta listar, com o privilégio de quem olha à distância aqueles com quem ela tem que compor (não é o regime do "racista em desconstrução"). Ela - a branquitude - tem que soltar o cultivo desse tipo de colheita (monocultivos,... extrativismos, planta-

\footnotetext{
13- Me lembro do ator "Gui"(Luiz Guilherme Ribeiro Cunha) da Companhia Teatral Ueinzz e sua maravihosa intervenção de interjeições que cortam, que quebram a narrativa, mostrando que uma fala pode ser sempre demasiadamente auto referente. Suas intervenções produzem, dentro e fora do palco, um corpo grupal daquilo que vai sendo dito, aqui e ali, e acolá, criando também uma ativação cênica do cotidiano. Link para um trecho da performance em Amsterdam (2016): <https://youtu.be/XHoS1FSCiFg> (Acessado em 10/10/2020)

14- Como nos vídeos de Veridiana Zurita, no canal "Sai Fetiche" exacerbando o narciso da branquitude, ou "branquitute". "Bora quebrar esse espelho, que reflete essa imagem tóxica" (2020). Disponível em <https:// youtu.be/c20jlcA5474>
} 


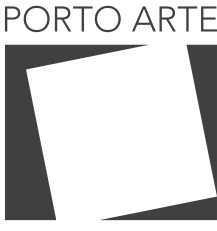

Revista de Artes Visuais

v. 25 ก. 44

$\mathrm{Jul} / \mathrm{dez} 2020$ e-ISSN: 2179-8001

tions, como sinaliza Jota Mombaça ${ }^{15}$ ). 0 que ela não pode perder de vista, de corpo, é desmontar como se desmonta e remonta o corpo numa roda de capoeira, o bailar como um corpo esgotado de Butoh. Muitas vezes não encontramos a maneira, e vamos no balbucio. Como se fosse um murmúrio que por similaridade encontra seus suplementos, de língua, de saliva.

A língua indígena. As línguas indígenas se aprendem em palavras esparsas. Lemos, em meio a estes balbucios, Mery Txama Xambé Puri e Daniel Tutushamum Puri e sua pesquisa da língua puri, reconstituindo um vocabulário de uma língua que se perde, e se perde porque a etnia se perde, mas se recupera, se refaz. "Txemín Puri" (Povo Puri) é o título da primeira pesquisa que eles publicaram em 2019, apresentada no Abril Indígena da Aldeia Maraka冈'na冈, na cidade do Rio de Janeiro ${ }^{16}$. Mery Txama e Daniel recuperam a história da etnia até a atualidade. Escrevem sobre sua constante diáspora, passando pelo desmanchamento das famílias por escravização, até terem sido declarados extintos - o que vem sendo contestado pelos próprios descendentes, nesse levante de sua história, sua língua, seus costumes. Como eu aprendo com?

\section{Inventamos conversas (encontrar-se, extraviar-se)}

Criamos um espaço de conversa, nesse dossiê (Instinto e Instituição), de nossos anteparos e de nossos desafios, e quando dizemos "nossos", não significa "nossos" porque nos pertencem porque foram perpetrados por nós, mas porque nos apropriamos dessas experiências, e nos deixamos afetar por elas com elas. Precisamos conversar a partir de multiplicidades, e diferentes posicionalidades desde una perspectiva micropolítica. Como aponta o colectivo Sans Ticket (CST) / Grupe de Recherche et Formation Autonome em Micropolítica de los Grupos: para una ecología de las prácticas colectivas:

\footnotetext{
Nos distanciamos de aquella aceptación que propone la existencia de un sujeto fijo, que comenta un punto de vista, desde su función, su estatus social, su historia, su posición (el lugar desde el que "mira"). El uso del término "punto de vista", remite a una fuerza remite al encuentro con una fuerza que obliga al pensamiento. $Y$ ese encuentro con un nuevo punto de vista no se puede atribuir a una identidad formada debido al hecho mismo que no disponemos de esquemas preparados para reconocerlo, ni disponemos a priori, hacer de él un objeto. (Vercauteren, et al, 2010, p. 170)
}

\footnotetext{
15- A autore denuncia um processo de extração, por agentes brancos, heterossexuais e cisgênere do circuito, de termos e práticas como queer, negritude, descolonização, desconstrução, feminismo, antirracismo, dissidência etc. que se tornam "moeda de troca no marco das negociações por fundos para [um] projeto" por parte de instituições de arte europeias, interessadas no valor atribuído tais conceitos e práticas. Trata-se de uma "economia especulativa, drenada a partir de forças de vida historicamente despossuídas de valor e, portanto, expropriadas do valor total de sua própria criação e trabalho" (p. 8). "Esse processo de extração ....) refaz o território político da plantação (plantation)". Jota Mombaça, "A Plantação Cognitiva". Em: Coleção Arte e Descolonização, MASP/Afterall, São Paulo, 2020. Disponível em <https://masp.org.br/uploads/ temp/temp-QYyCOFPJZWoJ7Xs8Dgp6.pdf> Acesso em 25/10/2020 16- Disponível em <https://www.scribd.com/document/408583992/Txemim-Puri-O-Povo-Puri-Historia-Cultura-Lingua-e-R-existencia>
} 


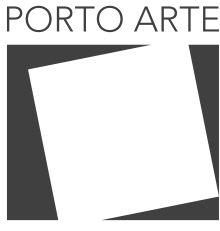

Revista de Artes Visuais v. 25 n. 44 Jul/dez 2020 e-ISSN: 2179-8001

Tentamos humildemente, às vezes torpemente, neste dossiê, recolher, coletar e plantar práticas e transmissões de intensificação de uma saúde menor. Criar, e mergulhar nas palavras que deixem a vida passar, vibrar. Como numa conversa xamãnica, abandonar certas palavras precisas, para agarrar nelas a sua vibração.

\section{Mutabilidade, imobilidade}

Ao final do ano, muitos de nós podem estar recobertos por uma saturação, uma espécie de infofobia ou infotoxia. A instituição da pandemia nos remete ainda mais às redes sociais e ao trabalho remoto como única versão de uma continuidade do mundo, mas essa conectividade é falha. Ela esconde tantos outros mundos, infimundos (infi de pequenos, e de infraestruturais). Mundos do trabalho reprodutivo da vida. Enfermeiras, educadoras, empacotadoras, vendedoras, faxineiras, cuidadoras, ... $\mathrm{Na}$ guerra das verdades enfrentamos mais uma espécie de esvaziamento, das noções ou potencialidades de público e da nefasta representatividade política, um debate incessante que destitui e restitui verdades, e mesmo se solidifica com a pandemia (fortalecimento de negacionismos). Uma crise que é também a do estado (como regulador onipresente...), uma crise que não parece possível, sequer, acessá-la. Uma crise que nos deixa deveras imóveis.

Diante das telas as identidades se reificam e se fortalecem como forma de expressão. Cabeças-falantes. Ora a tela se torna um apelo (da ordem do salve-me quem puder), ora a tela insistente de algum tipo de multiplicidade excessivamente vista. Talvez foi o ano em que ouvimos mais vozes pelos softwares de áudio de nossos computadores e telefones do que ao pé do ouvido. Na guerra dos sentidos todo som passa por uma filtragem e uma modulação que nos escapa. Desfazimento do caminho da intuição, na escuta.

Colocando em uso uma das ferramentas da análise institucional, a noção de analisador, deslocamos o vírus, um dos agentes da pandemia, ficando assim o final da frase deslocamos o vírus, um dos agentes da pandemia, para o lugar de um analisador. Segundo Simone Paulon (2005, p. 24), um analisador é um "dispositivo revelador das contradições de uma época, de um acontecimento, de um momento de grupo" e ele pode atuar numa espécie de desmonte, ou decomposição daquilo que parecia total, homogêneo, denso e imutável. 0 vírus se torna um analisador porque um analisador "desvela o caráter fragmentário, parcial e polifônico de toda realidade." O vírus é atravessado por concepções de uma saúde maior, colapsada, ora abandonada, e também fala das metodologias de uma saúde menor, dos movimentos pequenos da sobrevivência - das comunidades que se regeneram, das que se sustentam, ou se é que haviam; ou das comunidades que não existem. $O$ vírus de 2020 nos fala das condições singulares de vida, acesso a bens, trabalho, saúde, e expõe nossa alienação. 0 vírus expõe as instituições, suas falhas, seus buracos, e também, nossa capacidade de compor com, tanto com o vírus, como com outras formas de vida.

Esse compor com é uma forma de alçar, de "aliançar", de fazer-se com, não fazer-se por. E talvez o vírus expõe a crise das vidas alienadas, o distanciamento 


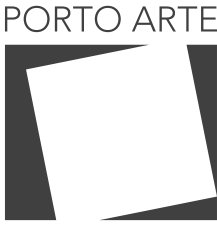

Revista de Artes Visuais

$\vee 25 n .44$

Jul/dez 2020

das formas comunitárias. A crise das formas de coletividade na atualidade talvez não seja tão nova, porque as formas de coletividade não tem, em si, qualquer essência ou estabilidade. Situando, contudo, nos posicionamentos feministas, encontramos como formas comunitárias ou coletivas (vilarejos, aldeias, bairros) foram desmontadas, por sua vez, por uma homogeneização de formas de trabalho e consumo. Maria Rosa Dallacosta e o movimento italiano feminista da segunda onda apontaram para as crises que a forma trabalho (pago, fora de casa) provocavam no espaço doméstico (o trabalho doméstico em contraste com o trabalho pago), aquele dependendo, por sua vez, da invisibilidade e não remuneração do trabalho doméstico ${ }^{17}$. A instituição da família, célula operativa nesse sistema heterosexual, afastou a forma comunitária, e não que a família tenha suplantado a comunidade de qualquer forma eficaz. A forma (ou fórmula) família depende do estabelecimento e da manutenção de uma série de morais e valores, tema que escapa em parte a este texto.

Estudos de processo grupal situados na psicologia social ancoram uma percepção crítica sobre a produção das noções de indivíduo e sociedade, num momento em que a fragmentação social era necessária para implementar (e solidificar) um sistema produtivo. Esse sistema que dependia, sobretudo, da exploração das individualidades, como dito acima, também atuou na produção de grupalidades sociais (tal como a noção de classe - produzindo a classe a ser explorada). Ao pensar (aqui, com os pés aqui) o lugar da coletividade, e na literatura que procura atuar nessa saúde menor, também a partir da vida das instituições da Saúde, Regina Benevides de Barros nos conta sobre uma atenção ao processo grupal como forma de instigar uma atenção pré-individual, atravessando, por sua vez, a alienação individuante (o centramento no indivíduo) cada vez mais reforçado pelos sistemas de produção de subjetividade no capitalismo corrente. Uma atenção ao processo grupal pode ser, por isso, forma de aliançar...

Pensar a forma grupal, em primeiro lugar é pensar como provocação de crise per se, de instigação ao movimento e à atenção inter-individual (e pré-individual), desestabilizando aquilo que parecia assegurado. Toda forma instituída de grupalidade é um constante produzir-se, há grupalidades, por isso, que não resistem a crises, não resistem à crítica de sua própria lei de organização (vale a distinção que Félix Guattari ${ }^{18}$, psicanalista, filósofo e ativista francês, fez entre grupo sujeito e grupo assujeitado ${ }^{19}$ ). Há uma circulação, portanto, entre individualidade e grupalidade.

\footnotetext{
17- "Na medida em que os homens foram os chefes despóticos da família patriarcal, baseados numa estrita divisão de trabalho, a experiência de mulheres, crianças e homens foi uma experiência contraditória que herdamos. Mas na sociedade pré-capitalista, o trabalho de cada membro da comunidade de servos era visto como direcionado para um propósito: ou para a prosperidade do senhor feudal ou para nossa sobrevivência. Nessa medida, toda a comunidade de servos era compelida a cooperar numa unidade de falta de liberdade que envolvia, na mesma medida, mulheres, crianças e homens, que o capitalismo tinha de romper" (DallaCosta, 1971).

18- Sobre a vida de Félix Guattari, recomendamos o artigo de Larissa Drigo Agostinho. "Guattari: máquinas e sujeitos políticos". Em: Trans/Form/Ação, Marília, v. 43, n. 1, p. 103-126, Jan./Mar., 2020. Disponível em: <https://www.scielo.br/pdf/trans/v43n1/0101-3173-trans-43-01-0103.pdf>

19- A distinção é trabalhada em vários textos, um dos textos de referência pode ser o próprio “Transversalidade", em Revolução Molecular (1981). Janell Watson e Gary Genosko são teóricos que vão trabalhar também nessa distinção proposta por Guattari, que pode não ser estanque em um processo grupal.
} 


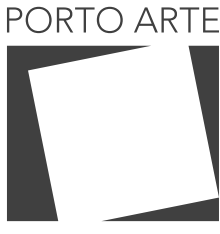

Revista de Artes Visuais

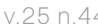

$\mathrm{Jul} / \mathrm{dez} 2020$ e-ISSN: 2179-8001
A noção de singularidade não se esgota nas composições unitárias e identitárias. Ela circula nos espaços da multiplicidade e da diferença ou, ousaríamos acrescentar, nos espaços públicos, no sentido que não podem ser explicados isolando-se dos processos históricos que os constituíram. (de Barros, 2014).

A atenção grupal, nos diversos processos que podem ancorar uma análise das instituições, pode abrir pesquisas de modos, visto que as instituições e seus sistemas de regulação operam tantas imobilidades (imobilidades molares, agenciadas e programadas por tantas macroinstituições como o mercado e o estado). Guattari escreve, em "Transversalidade", assim como em outras anti-fórmulas, que uma análise de grupo pode fazer brotar uma criatividade do grupo - trabalhando antes das rejeições e atrações. Se há, contudo, uma recusa do nonsense, é normal que a dinâmica se deixe voltar à palavra de ordem, à norma reguladora, "obturando qualquer acesso a uma fala verdadeira, isto é, articulável às outras cadeias do discurso histórico, científico, estético, etc" (Guattari, 1981, p. 94). A coisa é, para ele, recuperar um ponto autêntico de fala, que não seja centrado (em si), alimente muitas, muitas vizinhanças, de forma a poder mover-se ali, e mais um pouco.

\section{Guerra de sentidos, desafecção}

A partir de que ponto reorganizar a vida? A guerra sobre o sentido das coisas está aí também, a ponto de que quem nos "manda" cuidar-nos é o programa "Bem" da farmácia. A manutenção domesticada de nossos estados de bem estar anuncia os embotamentos de nossos sentidos. As diversas formas de se pensar a organização do cuidado relacionando-o à lutas e à auto-organização social procuram responder a essa captura, reprojetando valores e modos. Do meio da revolta à crise social e política chilena escutamos:

\begin{abstract}
Auto-organización espontánea de los cuidados, que excede la escucha psicológica de un sujeto, pero que acompaña al cuerpo-pueblo en su devenir de la subjetividad, o más bien en su dessubjetivación del estado de vaciamiento y agotamiento neoliberal en nosotres. Una alianza vibratoria entre el Cuerpazo del pueblo-cuerpo, y les escuchador-s, al servicio del devenir. (...) Como dice una nieta-pueblo: mis abuelos sobrevivieron a la dictadura, pero murieron en manos de la salud pública." (Cobo-Guevara, 2019)
\end{abstract}

Realidades cindidas, vírus. A primeira morte do Rio por coronavírus: empregada doméstica não foi informada de risco de contágio pela patroa, a patroa sobreviveu, a 


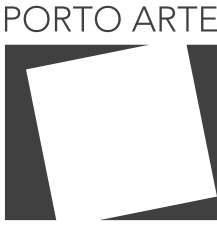

Revista de Artes Visuais

$\vee 25 n .44$

$\mathrm{Jul} / \mathrm{dez} 2020$ e-ISSN: 2179-8001

doméstica não ${ }^{20}$. Lhe foi negado um cuidado mínimo, básico, qualquer: a informação. A doméstica é substituída rapidamente por outra doméstica. Sabemos seu nome? Outra mulher também doméstica, e negra, tem seu filho morto em queda do $9^{\circ}$ andar porque uma mulher branca da elite Recifense...

Como andar por aí se não consigo tocar minha boca? Vou me distanciando do meu próprio corpo. A máscara recobre outros sentidos. E então esse split interno. Já não consigo, porque parece que já não sei olhar nos olhos de alguém, presencialmente, demoradamente. Como ser cuerpo-pueblo? Cuerpazo? Como não perder o tato, se já perdemos? Já vamos vivendo uma desafecção, como disse Peter Pál Pelbart ${ }^{21}$, no contexto da pandemia. "A desafecção, a indiferença, a absoluta denegação do risco, do perigo, da morte, da tragédia. Esse é o grande perigo político, psicopolítico que todos nós vivemos." Quais são os lugares, ou as formas, ou os espaços nos quais se pode apostar em um "comunismo dos afetos"? De que tipos de aliança isso depende? Em algum lugar disse Guattari: há uma precariedade radical e constante.

Leio no email que chega na caixa pessoal: "Em todo o Mediterrâneo, apenas um barco de resgate civil ainda está em operação: o Open Arms (Braços Abertos). Sua dedicação é impressionante, enfrentando guardas costeiras violentas, mares tempestuosos e uma tristeza diária. Eles já resgataram mais de 60 mil pessoas do mar". Open Arms não é nada mais que a imagem de uma extrema vulnerabilidade. Uma vulnerabilidade que tenta produzir qualquer rede de potências, nesse lugar mais que não lugar - o mar, aberto.

A migração precisa de um solo firme, de um solo para perseverar, mas é deixada à deriva, literalmente, como território último da vida (sic. morte). É como se a vida estivesse ali por alguns milisegundos num regime de visibilidade que, de repente, na verdade, já passou. (Vida que reaparece como morte.)

\section{Improvisação, imprevisto}

Estamos numa sala de um centro cultural. Somos todas mulheres. Estamos no terceiro ou quarto dia de uma oficina de improvisação teatral, com a consigna de pensar tanto a produção de vocabulários como a solidarização de nossos processos de vida. Ao começo do trabalho percebemos alguns aspectos em comum - temos nossas vidas atravessadas pelo cuidado e pelo trabalho reprodutivo (Ribas, 2019). Algumas como mães, ou como professoras e mães, algumas como professoras. Algumas são artistas, algumas atrizes, até com longa jornada já. Algumas são mais jovens, estão experimentando coisas. Analisamos como, e se, nos vemos reproduzindo lugares na sociedade que foram designados às mulheres. A instituição patriarcal desenhou esses papéis para nós? Como nos adaptamos a eles? Como assumimos esses papéis à nossa maneira? ${ }^{22}$

\footnotetext{
20- Ver matéria da Agência Pública <https://apublica.org/2020/03/primeira-morte-do-rio-por-coronavirus-domestica-nao-foi-informada-de-risco-de-contagio-pela-patroa/>

21- Neste dossiê, na conversa "Esquina do Mundo: a quarentena de um hospital de cuidados paliativos". 22- Nos referimos aqui à oficina "Vocabulários políticos: clínica da política", realizada por Cristina Ribas no Espacio de Arte Contemporáneo (EAC), em Montevideo, Uruguai, 2019
} 


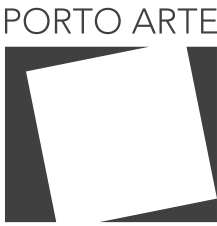

Revista de Artes Visuais

V. 25 ก. 44 Jul/dez 2020 e-ISSN: 2179-8001
Figura 5: Liliana Gonzáles e Katty Gancharov na Performance final da oficina Vocabulários políticos: clínica da política realizada por Cristina Ribas, com dez participantes, no Espacio de Arte Contemporáneo (EAC) Montevideo, 2019

Recupero da memória, com um pouco de dificuldade, a narrativa que não fiz no momento. Deveria ter gravado áudios, para mim mesma, como me disse Liliana, para que eu não esquecesse de como o processo grupal se desenvolvia, de como os jogos de improvisação mudavam e se sucediam, em parte quebrando o próprio protocolo que eu havia criado, em parte adaptando-se ao que o grupo tinha necessidade e, na tradução constante de línguas português-espanhol, eram reinventados por todas. Num dos jogos propostos, fizemos um exercício de transdução narrativa, sonora e corpórea que eu já havia realizado algumas vezes com outros grupos. Seguindo o Teatro do Oprimido, trabalhando em duplas, fez-se, uma para a outra, a narração de uma experiência, no nosso caso, uma experiência de violência de gênero. Enquanto uma escutava, a outra buscava expressar em som, criando uma partitura dessa narrativa. Depois o grupo voltava a se reunir, sendo criada uma escuta coletiva dessas "peças sonoras". Aparecem cenas delicadas, com sons íntimos. 0 acesso que aqueles lamentos, murmúrios ou gritos de assombro nos dão à experiência antecipa qualquer coisa que a palavra pudesse tentar passar. 0 som parece que transporta mais afeto. Aquilo que foi sentido transmuta em som, atinge com vibração meu corpo.

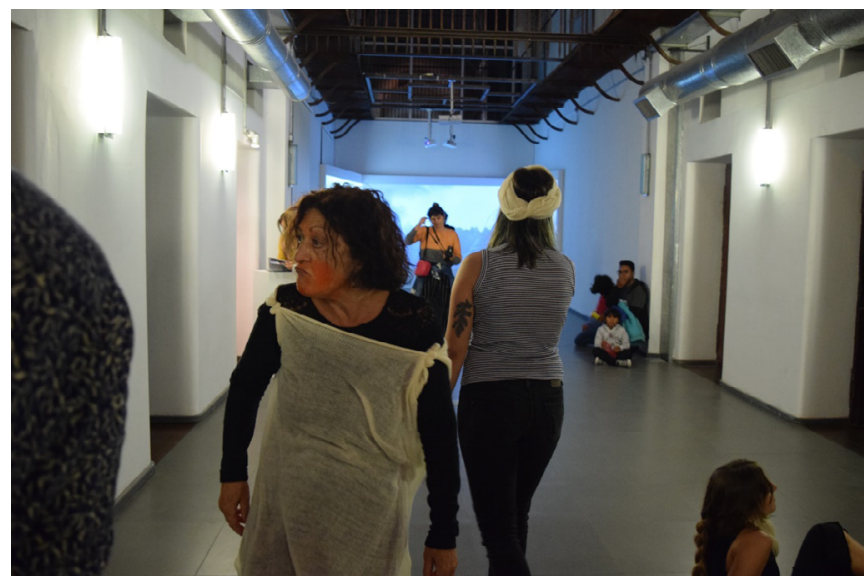

Figura 6: Liliana Gonzáles e Katty Gancharov na Performance final da oficina Vocabulários políticos: clínica da política realizada por Cristina Ribas, com dez participantes, no Espacio de Arte Contemporáneo (EAC). Montevideo, 2019

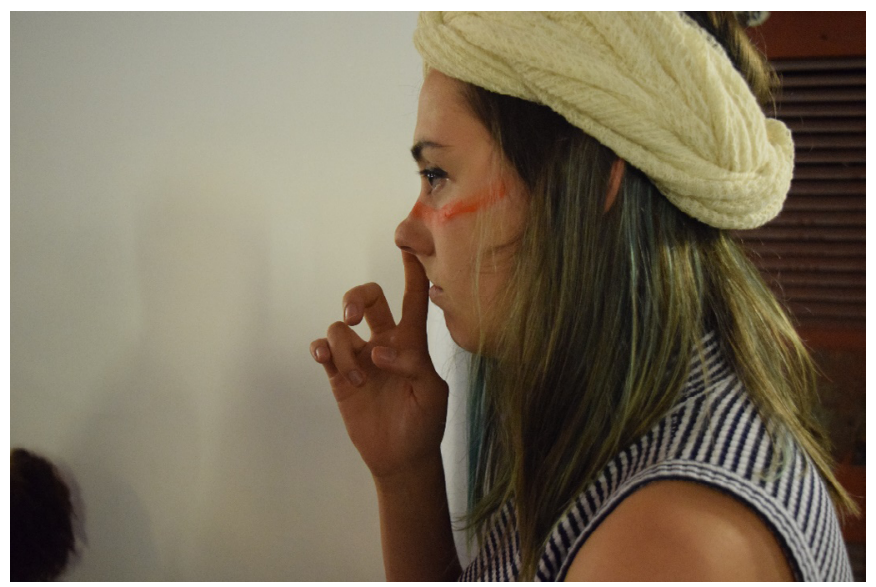




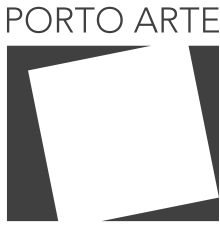

Revista de Artes Visuais

v $25 n .44$

Jul/dez 2020 e-ISSN: 2179-8001

A performação de uma dor, de um momento tenso, de uma virada. Mas o que se manifestava não permanecia como dor, se transformava em algo além. Inauguramos mais um ponto no processo delicado do conhecer-se. Trabalhando violência de gênero nos conhecemos também nas nossas forças, imprevistas. Numa das cenas, a participante se afasta de nós, e é como se formássemos uma pequena plateia. Ela tira a camiseta enquanto nos olha fixamente e executa seu protocolo sonoro. Tem algum lamento, mas tem também alguma ira. Nos tornamos testemunhas de uma cena: seus seios à mostra, $\mathrm{e}$ então ela nos olha como se olhasse para homens. Entendemos sua força. $E$ a reviravolta que aquilo causa. Nela, em nós. Delicadeza e presença, um urro silencioso daquilo tudo que se projeta sobre corpos femininos. Enchemos os olhos de água no desejo, talvez, de libertar essas projeções, e encontrar uma expressão singular - para os seios, para a nudez, mas também para um modo de existência. Onde se ampara a impossibilidade de perceber a singularidade de uma expressão, e de respeitá-la? 0 gesto desmonta o comando da objetificação, mesmo que ela venha seguida de repulsa. Algo se transforma.

Não tivemos acesso a um relato objetivo, o exercício nos fazia desviar do intento mesmo de representar o vivido. Repetir poderia ser falar. E visto que, para diferir, parece que é preciso abrir um espaço que inaugure uma improvisação de movimento, em que a imagem projetada pelo outro possa derivar e desviar daquilo que encerraria uma existência em uma imagem - que poderia ser julgada, subjugada, invalidada. Performando gestos coletivos quando nos escutamos, dançamos alguma invenção de comunalidade. Depois de muito falar, eu intervinha. Hora ou outra era preciso calar. Tocar os pés nos chão novamente, e reiventar-se em uma cena que pudesse bagunçar nossos enunciados. Bailar como se baila nas ruas em protesto em Montevideo. Ou protestar cantando não uma palavra de ordem, mas uma canção de meninas, como elas fizeram.

No testemunho de nossa própria intimidade, na inauguração de alguma agência coletiva reconheço que é como se nossos corpos fossem se movendo para fora de blocos de bloqueio. Por um lado, eliminando as projeções iniciais, por outro arriscando naquela espacialidade que nos reorganizava. Eu olho para toda aquela montagem, e já não consigo situar em um único espaço de significação. Escapamos à arte, escapamos à militância, escapamos a uma clínica coletiva, grupal ... Ao longo dos dias em que estivemos juntas concebemos uma performance final para uma abertura de ciclo de exposições na instituição de arte que nos acolhia, e naquela noite tinha algo mais que nos segurava juntas - algo mais que a consigna de realizar uma performance. Levávamos juntas um espaço de vulnerabilidade que reaparecia na instituição artística, mas destituído de uma vontade racional-discursiva que localizasse essa devolutiva naquela separabilidade entre, como disse bem, Simon O'Sullivan, pensando Lyotard, "produção e recepção". Deslocando desse lugar, nos agarramos mais, talvez, ainda como diz ele, à capacidade que o encontro tem de "sustentar uma promessa, de uma infinidade de formas e comentários, e, através dessa infinidade, a promessa de uma comunidade de sensação" (O'Sullivan, 2006, p. 38-39). Isso seria uma forma de afirmar tanto a imprecisão do procedimento (não sem compreender a precisão desejada de alguns de seus efeitos), mas o excesso, a quebra, que ele provoca, em nós mesmas. Há um imprevisto que isso tudo provoca, em nós, na experiência, e nos seus efeitos. 


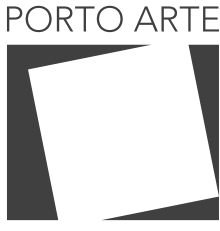

Revista de Artes Visuais

v $25 n .44$

Jul/dez 2020 e-ISSN: 2179-8001

\section{Farejar instituições, corredores e escadarias}

Se as instituições da arte têm uma esquizofrenia que as atravessa, como diz Luiza Proença (em texto nesse dossiê: "Arte e resistência micropolítica"), como podem as instituições não resultarem nessa esquizofrenia, mas sim "numa reconfiguração de sua cartografia sociocultural?" Da mesma forma, os demais espaços, as grupalidades que agenciam a arte, a universidade como instituição que não duvida das vias de codificação da arte (e bloqueia procedimentos de análise) reinscrevem muitas vezes a afirmação de uma segurança pautada em certas formas, que, reconhecíveis, evitam a saúde menor da arte, que seria talvez uma arte de a menor, de a minúsculo, de potência instituinte. Da simplicidade do gesto. Luiza Proença pergunta se a escuta de uma potência estranha (insurgente) que corre por fora dos museus - rumores e gritos, línguas sem posse, só de passagem - pode ser maneira de fazer do museu um museu-clínica, um museu hospitaleiro. Quando visito museus me dou conta de como meu corpo está acostumado com aquele espaço, sou uma mulher branca, aprendi os rituais, reproduzo as neuroses que preservam aquela instituição - ou quando me desvío acontece a medicalização, o processo de patologização e manicomialização como aponta el colectivo de antipsiquiatría feminista chileno, NO ES LO MISMO SER LOCA QUE LOCO. A presença objetual da experiência (institucional) parece que abafa a experiência estética que corre, aí, assim, desaparecente. Asilar na arte (como asilo para Tosquelles), asilar a arte (esse objeto desterritorializado). Isso não seria reconhecer de novo na arte que ela é passagem de afeto, o si o si?

Muitas vezes parece que as instituições da arte conseguem desviar-se de um enfrentamento de suas estruturas de reprodução, mas evidente que não são só elas. A violência que operam os museus como forma de domesticação da experiência estética tornou-se uma forma de controle também da significação e dos sentidos. Quem se lembra do "caso" Caroline Pivetta na Bienal de Arte de São Paulo?; e, naquele momento a instituição artística atuando como normativa social, redesenhando o comportamento (exemplar), o patrimônio, a posse da significação da experiência institucional da arte? A instituição se refez normativa como uma moral institucional e social em geral (estatal?), e nessa reflexividade de sua ação devolveu à sociedade a identidade criminal de uma mulher, que, antes de qualquer coisa, não podia ser artista. Aparece a instituição de arte contra a mulher grafiteira, sem trabalho, sem residência fixa.

O museu decolonial vem rompendo, contudo, aquela produção cafetinada, uma mudança estrutural. Uma mudança que trata de atiçar todo o recoberto (o racismo, a misoginia, os abusos), de fazer denúncia, e trata de, ao mesmo tempo, perder a função, para reencontrar uma função estética, diagramática, de passagem. Complicadas trampas, no Brasil e alhures, de reescrever nossas histórias sobre e com os silenciamentos, de forma a fazer reaparecer ali "dentro" toda potência de arte resiliente e constitutiva de um fora. Saúde menor, mas arte com "a" minúsculo, e mais-que-o-museu. Mais que o museu, suas passagens, seus corredores ${ }^{23}$, suas calçadas, seus porões, seus acervos 


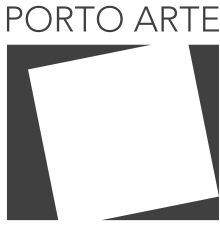

Revista de Artes Visuais

$\vee 25 n .44$

$\mathrm{Jul} / \mathrm{dez} 2020$ e-ISSN: 2179-8001

(como na pesquisa de Izis Abreu, revelando o racismo e o elitismo constitutivo da coleção de um museu estatal). Mais que o mármore, suas fissuras.

Para encontrar instituintes é preciso abandonar os objetos bem definidos. É preciso encontrar (pares) instituintes. É preciso vestir outras identidades. Acercar-se de campos de indefinição, trocar de pele. E colocar em suspenso a ideia de uma pré-existência tanto dos sujeitos do conhecimento como dos objetos a serem conhecidos (Passos, Kastrup e da Escóssia, 2009, p. 202), farejando pelos cantos dos corredores, de um anti-especialismo, as formas de criar parcerias nessas alianças de vulnerabilidade. $\mathrm{E}$ que passam também por si, que explicitam a conexão subjetivo-instintiva. Essa é também, de uma certa forma, uma cartografia animalesca, mais-que-humana, zorra-pós-humana, ou da raposa (Paul Preciado). Se o diagrama faz (acontecer) e não representa, ele produz (Guattari). Assim também fareja o desejo.

Mas como abandonar a atenção molar, como disse Guattari, aquela orientada a reconhecer de modo formalista, estruturalista, sistêmico? Como ativar uma atenção processual, que possa dar conta de olhar, estar, submergir em "cada componente de passagem"? Política ou mergulho molecular, podemos dizer, animismo menor. Ainda menor.

\begin{abstract}
A entonação deverá ser colocada [na] análise dos procedimentos específicos de transformações próprias a cada componente de passagem. Em que elas modificariam os "usos" anteriores das populações moleculares e das matérias de expressão? Em que elas molecularizam a política do conjunto de componentes? (Guattari, 1988, p. 181)
\end{abstract}

O que propõe Guattari se projeta no dia a dia de nossas práticas. Refuta o racional-consciente. Está no espaço (amplo, tentacular, arácnido) da pesquisa, está no espaço da criação. E está, como na clínica do cotidiano de Miguel Norambuena, também na clínica, que é, guatarianamente e animisticamente, ecosófica: "na qual se passa de uma lógica ego-antropo-concéntrica, normativa e redundante, desmaterializada e "euzista" (yoista) majoritária a uma lógica des-individual" (neste dossiê). Passagem de saber, institucional, de aqui para ali.

"O homem é um animal se despojando da espécie", escreveu Deleuze (2004, p. 137). Arrancando suas peles do animal (desconhecido?) de que se despoja, deixando de grasnar, diz Suely Rolnik (2015) que "cada morte de uma figura do humano tende a ser vivida como aniquilamento de tudo". E segue, "esta sensação pode levar a reações patológicas, e aí já caímos num outro domínio, o da clínica." Mas como viemos atentando, não se tratam de passagens topológicas, de um campo a outro. A clínica do cotidiano, em nossas práticas, vai querer acolher o desassossego, quando ele é fluxo. Sustentá-lo.

O grasnar do bicho (em nós) faz parte de uma ecosofia que possa se aliançar com nossas histórias. Os caminhos da criação, de meter-se com, alguma pragmática, um traçado, mais uma análise histórica do movimento institucionalista no Brasil, e da deco- 


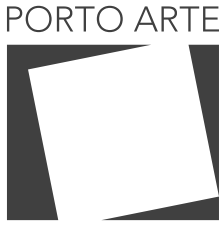

Revista de Artes Visuais

v. 25 n. 44

$\mathrm{Jul} / \mathrm{dez} 2020$ e-ISSN: 2179-8001

Ionialidade/descolonização, mais a criação de um grupo de pesquisa, como dispositivo não só de formação, mas de intervenção, de deformação institucional. Escutar, como se escuta a um ecossistema, também as instituições da arte (e da arte na universidade) e seus corredores, e seus porões, também para compreender condições de acontecimento, hoje, de processos estéticos que se projetam à ancestralidades, novas alianças que associam a produção de conhecimento e criação em redes de produção que atuam, nas passagens, de forma transversal. Para poder encontrar a experiência estética de outra forma é preciso pensar com o estômago, com o peito, com esse saber que não sabe que sabe, com algum saber do corpo (decolonial, instintivo), esse que nos foi expropriado. Como falávamos de uma escrita intestina, de uma instituição feminista, que se move em diferença às visibilidades e às políticas de validação. Uma cartografia de processos, e rastejante, pode trazer modos e escalas menores, bem menores (e ainda, ambíguas), pelas quais as expressões criativas acontecem, e ainda insurgem a partir de outras contaminações e co-laboratórios sociais (e de mídia, e maquínicos, e compositivos).

\footnotetext{
A arte é assim uma reserva ecológica das espécies invisíveis que povoam nosso corpo-bicho em sua generosa vida germinativa; manancial de coragem de enfrentamento do trágico. De acordo com os contextos históricos, varia o grau de permeabilidade entre esta reserva de heterogênese e o resto do planeta, o quanto o planeta respira seus ares. (Rolnik, 2015, p. 105)
}

Sem querer situar o inconsciente institucional da arte, apostamos nessa passagem de saber; neste sentido, não encontramos um inconsciente não recoberto, não dentro, mas disponível. Para poder encontrar a experiência estética de outras formas é preciso muitas vezes topar com ela por fora do circuito (das artes visuais, performáticas, dos discursos de interpretação, por fora das instituições culturais como espaços de intermediação e encontro com públicos vários) e rastejar, de outra forma, por "cartografias mutantes", "em contraste com os disciplinados mapas dos especialistas" (Rodrigues, Sá Leitão e De Barros, 1992, p. 15). Essa transformação não é um lá, um perder-se topograficamente, em outro lugar, mas aqui mesmo, com os pés nesse lugar.

Algo disto podemos trazer de experiências de outros registros de produção como é o movimento das clínicas públicas de psicanálise no Brasil, como nos conta a psicanalista, Ana Carolina Perella do coletivo Clínica da praça Roosevelt, num setting clínico, performático no centro da megacidade de São Paulo. Ana Carolina nos comenta sobre os limites da psicanálise no exercício de uma clínica que se dá em meio da vida urbana". Nos faz refletir sob a seguinte pergunta em seu texto apresentado neste dossiê: 


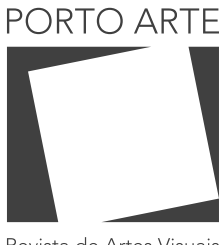

v. 25 n. 44 Jul/dez 2020 e-ISSN: 2179-8001
É, então, a partir da desestabilização de um plano de organização que o corpo da clínica pode se abrir à pulsação da cidade, instaurando assim outros tempos e outras possibilidades de vida. Nesse sentido, que forças se atravessam e quais efeitos se dão quando a clínica, a psicanálise e a praça se encontram?

A modo de conclusão, voltamos às primeiras palavras com as quais inauguramos e lançamos algumas ideias-força, sob o que poderia ser um inconsciente menor institucional: aquele que é expulsamento mais que qualquer outra coisa. Esta problemática nos coloca frente a um problema de modos de relação, entre forças e modos. Poderíamos dizer que o "enfermo" não é produzido pelo enfermo ele mesmo (sozinho), mas é produzido por um modo, um modo de instituição. Por tanto poderíamos dizer que a saúde menor de uma instituição é a capacidade de destruir, traspasar fronteras, desbordar-se, revelar-se: instaurar uma passagem. Neste sentido, e segundo Tosquelles, "A loucura é uma criação, não uma passividade."

\section{Referências}

de Barros, Regina Benevides. Grupalizar é preciso.Rede Humaniza SUS. 2014 Disponível em <https://redehumanizasus.net/87759-grupalizar-e-preciso/>

Cobo-Guevara, Paula. Hacia Una Clínica Extranjera. Pontifícia Universidade Católica de São Paulo, 2021. [tese de doutorado]

Cobo-Guevara, Paula. Hasta que valga la pena vivir. Urucum, 27 de Outubro de 2019. Disponível em <https://urucum.milharal.org/2019/10/27/hasta-que-valga-la-pena-vivir/> Acesso em 10/03/2020.

Dallacosta, Maria Rosa. Mulheres e a Subversão da Comunidade (1971) Disponível em: <https://medium.com/qg-feminista/mulheres-e-a-subvers\%C3\%A3o-da-comunidade-de-mariarosa-dalla-costa-b7449ee52519> Acesso em 05/03/2020

Deleuze, Gilles. Instinto e Instituição. Ilha deserta e outros textos. São Paulo: Editora Iluminuras, 2004.

Deleuze, Gilles. Crítica y Clínica. Barcelona: Editorial Anagrama, 1996.

Deleuze, Gilles; Guattari, Félix. Mil platos - capitalismo e esquizofrenia. Rio de Janeiro: Ed. 34, 1995.

Flores, Val. Una lengua cosida de relámpagos. Buenos Aires: Hekht, 2019

Guattari, Félix. Psicanálisis y Transversalidad. Buenos Aires: Siglo XXI, 1976

Guattari, Félix. Transversalidade. In Revolução Molecular. Pulsações Políticas do Desejo. São Paulo: Brasiliense, 1981.

Guattari, Félix. O Insconsciente Maquínico. Campinas: Papirus Editora, 1988.

Guattari, Félix. Caosmose. Um novo paradigma estético. São Paulo: Editora 34, 2008.

Gallio, Giovanna; Constantino, Maurizio. François Tosquelles e a Escola da Liberdade. Saúde \& Loucura, no. 4 (Grupos e coletivos). Gregório Baremblitt e Antonio Lancetti (org.) São Paulo: Editora Hucitec, 1994 (p. 85-128). 


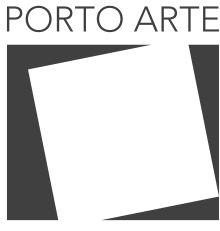

Revista de Artes Visuais

v.25 n 44 Jul/dez 2020 e-ISSN: 2179-8001

Massumi, Brian. O que os animais nos ensinam sobre política. São Paulo: Editora n-1, 2017.

Nietzsche, Friedrich. Asi Habló Zaratustra. Madrid: Alianza Editorial, 1972.

O'Sullivan, Simon. The Ethicoaesthetics of Affect and the Bloc of Sensations Reaffirming the Specificity of Art (Against Representation) In Art Encounters: Deleuze \& Guattari. Hampshire, New York: Palgrave MacMilan, 2006.

Oury, Jean. O Coletivo. São Paulo: Editora Hucitec, 2009.

Oury, Jean; Porto, M.; Almeida, A. C. M.; Breyton, D.; De Cardoso, M.; Hotimsky, S.; Markusszower, S. Jean Oury - Quando a neutralidade é uma doença. Revista Percurso - $O$ bem- e o mal-estar, no. 44, ano XXIII, Junho de 2010. Disponível em <http://revistapercurso.uol.com.br/index.php?apg=artigo_view\&ida=111\&ori=entrev>

Passos, E., Kastrup, V., e Escossia, L; (org), Pistas para o método da cartografia. Porto Alegre: Sulina, 2009.

Passos. E, de Barros, Regina B. A cartografia como método de pesquisa-intervenção. Passos, E., Kastrup, V., e Escossia, L, 2009. (p. 17-31)

Paulon, Simone. A análise de implicação com ferramenta na pesquisa-intervenção. Psicol. Soc. [online]. 2005, vol.17, n.3, pp.18-25. ISSN 1807-0310. https://doi. org/10.1590/S0102-71822005000300003.

Pál Pelbart, Peter. Da Clausura Do Fora Ao Fora Da Clausura Loucura e Desrazão. Primeira edição. São Paulo: editora brasiliense, 1989.

Pál Pelbart, Peter. A Vertigem Por Um Fio: Políticas Da Subjetividade Contemporânea. São Paulo: Iluminuras, 2018.

Pál Pelbart, Peter. Notas sobre o contemporâneo. Revista Mesa/ Instituto Mesa. Disponível em <institutomesa.org/RevistaMesa_3/think-piece/> Acesso em 20/11/2019

Ribas, Cristina T. Rimana..., ritmanali..., ritmanalizações vo-ca-bu-lo-políticas. Revista Arte Contexto (Verbetes da Arte), V.6, N¹5, MAR., ANO 2019. Disponível em

$<$ http://artcontexto.com.br/portfolio/ritmana-ritmanali-cristina-thorstenberg-ribas/>

Rodrigues, H., Leitão, M. B. e de Barros, R. D. B., Grupos e Instituições em Análise. Rio de Janeiro: Editora Rosa dos Tempos, 1992.

Rolnik, Suely. Lygia Clark e o híbrido arte/clínica. Concinnitas. Revista do Instituto de Artes da UERJ. v. 1, n. 26 (2015). Disponível em

<https://www.e-publicacoes.uerj.br/index.php/concinnitas/article/ view/20104/14402>

Ruiz, Valéria Salek; Athayde, Vladimir; Ribeiro, Mariska; Nogueira Filho, Irapoan; Zambroni-de-Souza, Paulo César; e Athayde, Milton. François Tosquelles, sua história no campo da Reforma Psiquiátrica / Desinstitucionalização e suas pistas para uma abordagem clínica do trabalho centrada na atividade. Estudos e Pesquisas em Psicologia. Rio de Janeiro v. 13n. 3p. 855-877, 2013.

Schiavon, João Perci. Pragmatismo Pulsional, Clínica Psicanalítica. São Paulo: n-1 Edições, 2019.

Samsonow, Elisabeth von. Anti-Electra, The Radical Totem of the Girl. Minneapolis/London: University of Minnesota Press, 2019. 
PORTO ARTE

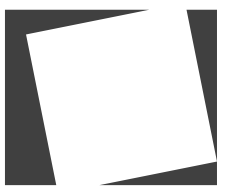

Revista de Artes Visuais

v. $25 \mathrm{n} .44$

Stengers, Isabelle. LEMBRA-TE DE QUE SOU MEDÉIA Medea Nunc Sum. Pazulin, 2000.

Vercauten, Oliver; Crabbé, Olivier \& Muller, Thierry. Micropolítica de los grupos. Madrid: Traficantes de Sueños, 2010.

WINNICOTT, DONALD. O brincar e a realidade. São Paulo: UBU Editora, 2019 


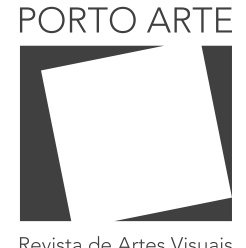

Revista de Artes Visuais

V. 25 ก. 44 Jul/dez 2020 e-ISSN: 2179-8001

Texto submetido em 20/11/2020 Texto publicado em $30 / 12 / 2020$

\section{Cristina Thorstenberg Ribas}

Trabalha entre a clínica e as artes. É Doutora pelo Goldsmiths College University of London (2017) e pós-doutoranda no PPGAV-IA UFRGS (CAPES PNPD) desde 2018, universidade na qual se graduou em artes em 2004. É Mestre em Processos Artísticos Contemporâneos pela UERJ (2008). Concebe projetos entre estética e política e pesquisa militante. Pesquisa análise institucional e estudos da subjetividade em relação à criatividade. Mais recentemente tem se envolvido com estudos feministas. Concebeu e editou o livro 'Vocabulários políticos para processos estéticos' (2014). Faz parte da Red Conceptualismos del Sur e do grupo de pesquisa Epistemologias Afetivas Feministas. Junto de Giseli Vasconcelos e Tatiana Wells desenvolve os Arquivos Táticos < http:// midiatatica.desarquivo.org/>. Organiza a plataforma online Desarquivo.org.

\section{Paula Cobo-Guevara}

Trabalha entre a clínica e as artes. Mestre em Estética na School of Critical Studies, California Institute of the Arts (CalArts) e MFA em New Genres, School of interdisciplinary studies, San Francisco Art Institute. Desde 2015 estuda continuamente no campo da clínica psicanalítica, no iPsi Centre (Barcelona, Catalunya) e no Campo do Fórum Lacaniano. Tem trabalhado nos cruzamentos entre artes, política, clínica e processos coletivos jun-to com Manuela Zechner no dispositivo de pesquisa feminista Murmurae. Ativista pelo movimento Right to the City e Freedom of Movement em redes migrantes em Barcelona e na Grécia junto com a artista Angela Melitopolous em Crossings, e pelo movimento de antipsiquiatria feminista. Atualmente é doutoranda no Núcleo de Estudos da Subje-tividade da PUC-SP. 